\title{
Influence of cement type and type of aggregate on the fresh and hardened properties of UHPC and HPC
}

\author{
Philipp Hadl, Hoang Kim, Nguyen Viet Tue \\ Institute of Structural Concrete, Graz University of Technology, Austria
}

Costs for the production of High and Ultra-High-Performance Concrete (HPC and UHPC) can be reduced by using locally available materials. Therefore, this contribution focuses on the influence of cement type on the fresh and hardened concrete properties of self-compacting HPC and UHPC. Eight different types of cement from different cement manufacturers were used in this investigation and were tested for their suitability for the production of HPC and UHPC.

In order to determine the cement's different water demand, an existing UHPC standard recipe, developed at the Institute for Structural Concrete, has been modified for each cement type. The aim was to produce a self-compacting UHPC with each type of cement. The experimental test results demonstrate that compressive strengths $>150 \mathrm{~N} / \mathrm{mm}^{2}$ are only possible with Portland Cements with low water demand.

Furthermore, the influence of cement type and aggregate on the fresh and hardened properties of self-compacting HPC was determined.

\section{Keywords: UHPC, HPC, cement type, aggregate, compressive strength}

\section{Introduction}

In recent years, extensive research activities have been undertaken in the field of Ultra High Performance Concrete (UHPC). Concrete mixtures, material properties and design recommendations as well as structural behaviour of this new material have been studied over the last decades at different institutions. As a result, the essential properties of UHPC and design rules for the main stress states such as tension, compression, bending and shear are adequately understood (DAfStb, 2007, Fehling et al, 2013; Leutbecher, 2012, Reichel, 2010).

Despite its extraordinary mechanical properties and excellent durability aspects, UHPC has been mainly used for pilot projects up to now. The main reasons for this are a lack of experience on the part of both engineers and builders, as well as the high material costs.

By using locally available materials, the costs for the production of UHPC can be reduced. While quartz powder (QP), microsilica (MS), quartz sand (QS) and superplasticizer (SP) are scarcely available regionally, cement (CEM) and aggregates are produced almost everywhere. The present paper describes the influence of cement and aggregate types on the fresh and hardened UHPC properties.

In addition to the grading curve and packing density, the type of cement, the de-airing process and the w/c ratio are decisive for the compressive strength of self-compacting UHPC (Richard et al., 1995; de Larrad, et al., 2002; Fehling et al., 2013; Geisenhanslüke, 2008; Kim et al., 2016). In this contribution, only the influence of the type of cement and the w/c ratio has been investigated. Due to the very high flowability of all concretes, the influence of de-airing has been excluded. The influence of the different levels of fineness of cement (blaine value) on the particle size distribution and the packing density has not been investigated as well. 
Influence of cement type and type of aggregate on the fresh and hardened properties of UHPC

\section{Experimental Investigations on UHPC}

The aim of this research is to produce self-compacting UHPCs with a compressive strength $>$ $150 \mathrm{MPa}$ with eight different cement types from various manufacturers. Portland Cements (CEM I) as well as Portland Slag Cements (CEM II/A-S) of category 42.5 and 52.5 with normal $(\mathrm{N})$ and rapid $(\mathrm{R})$ hardening have been used. The self-compacting properties require high flowability with spread values (haegerman flow) above $300 \mathrm{~mm}$, to ensure self-consolidating and good release of entrapped air during casting. At the beginning, the water demand for standard stiffness according to EN 196-3 (Austrian Standards Institute, 2010b) and the blaine value according to EN 196-6 (Austrian Standards Institute, 2010c) have been determined for all types of cement. Further, the compressive strength in the cement standard test according to EN 196-1 (Austrian Standards Institute, 2010a) after 1 day and 28 days has been determined (Tab. 1).

Table 1. Used types of cement and test results of the cement standard tests

\begin{tabular}{|l|c|c|c|c|c|c|c|c|}
\hline & C1 & C2 & C3 & C4 & C5 & C6 & C7 & C8 \\
\hline Type & $\begin{array}{c}\text { CEM I } \\
52.5 \mathrm{~N}^{*}\end{array}$ & $\begin{array}{c}\text { CEM I } \\
42.5 \mathrm{R}^{*}\end{array}$ & $\begin{array}{c}\text { CEM I } \\
42.5 \mathrm{~N}\end{array}$ & $\begin{array}{c}\text { CEM II } \\
42.5 \mathrm{R}\end{array}$ & $\begin{array}{c}\text { CEM I } \\
42.5 \mathrm{R}^{*}\end{array}$ & $\begin{array}{c}\text { CEMI } \\
42.5 \mathrm{R}\end{array}$ & $\begin{array}{c}\text { CEM I } \\
42.5 \mathrm{~N}\end{array}$ & $\begin{array}{c}\text { CEM I } \\
42.5 \mathrm{R}^{*}\end{array}$ \\
\hline Blaine [cm $/ \mathrm{g}]$ & 4500 & 3900 & 3630 & 4400 & 4150 & 5415 & 2800 & 4600 \\
\hline Water demand [\%] & $27-28$ & 27.3 & 27 & 30.4 & 27.7 & 30.4 & $25-26$ & 29 \\
\hline $\begin{array}{l}\text { Compr. Strength 1d } \\
\text { acc. to 196-1 [MPa] }\end{array}$ & 20 & 16 & 9.3 & 16 & 15 & 29 & 10 & 14 \\
\hline $\begin{array}{l}\text { Compr. Strength 28d } \\
\text { acc. to 196-1 [MPa] }\end{array}$ & 61 & 61 & 62 & 59 & 58 & 56 & 54 & 57 \\
\hline
\end{tabular}

${ }^{*} \mathrm{C}_{3} \mathrm{~A}$-free

\subsection{Method}

The various cements have different chemical compositions and blaine values, and therefore different water demands. The cement's different water demands must be taken into account in the concrete mix design. Therefore, an existing UHPC standard mixture (Kim et al., 2016) with self-compacting properties has been modified for each type of cement. Tab. 2 presents the standard UHPC mixture with a volume of paste $\mathrm{V}_{\mathrm{P}}$ (CEM, MS, QP, W, SP) of $568 \mathrm{ltr} / \mathrm{m}^{3}$ and a $\mathrm{w} / \mathrm{c}$ ratio of 0.28 .

Table 2. UHPC standard mixture

\begin{tabular}{|l|c|c|c|c|c|c|}
\hline & cement & $\begin{array}{c}\text { Microsilica/quartz } \\
\text { powder }^{* 1}\end{array}$ & water & superplasticizer & $\begin{array}{c}\text { quartz } \\
\text { sand 1 }\end{array}$ & $\begin{array}{c}\text { quartz } \\
\text { sand 2 }\end{array}$ \\
\hline$\left[\mathrm{kg} / \mathrm{m}^{3}\right]$ & 720 & 310 & 181 & 28.8 & 272 & 817 \\
\hline
\end{tabular}

${ }^{* 1}$ Microsilica and quartz sand premixed, see (Hadl et al., 2015)

In order to consider the cement's different water demand, one option is to systematically adapt the w/c ratio of the UHPC recipe. Another method is to increase the volume of paste by keeping the paste composition constant (amount of microsilica, quartz powder and superplasticizer are based on cement mass and remain constant). Both methods have been used in this research. Figure 1 demonstrates the procedure used for quantifying the cement properties and shows whether it is suitable for the production of self-compacting UHPC or not. 
Influence of cement type and type of aggregate on the fresh and hardened properties of UHPC

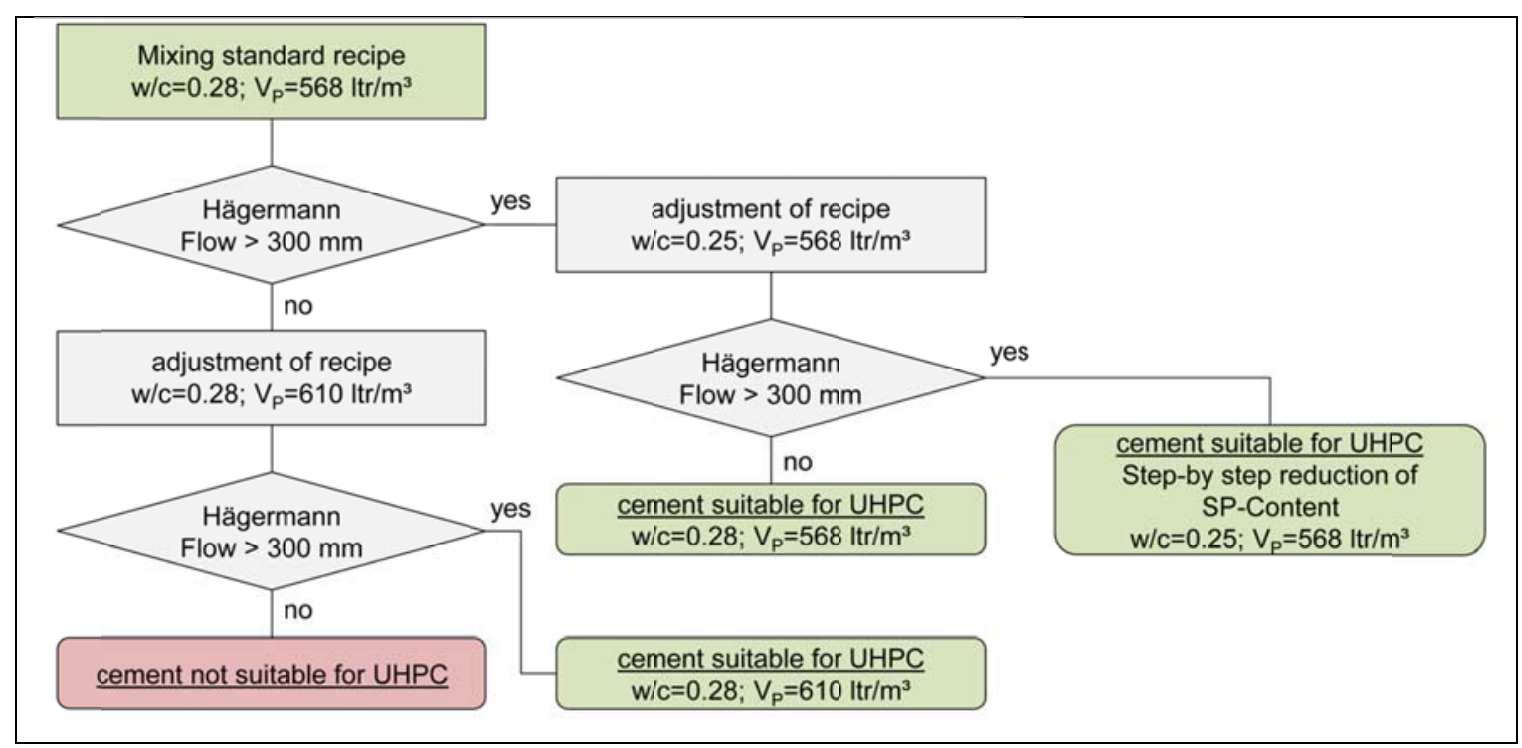

Figure 1. Procedure to quantify a cement and show whether it is suitable for the production of selfcompacting UHPC based on its fresh concrete properties (flowability)

At the beginning, the standard recipe is mixed with each type of cement and the flowability is determined then. If it is smaller than $300 \mathrm{~mm}$ in the spread flow test, the volume of paste will be increased to $610 \mathrm{ltr} / \mathrm{m}^{3}$. If the flowability is still smaller than $300 \mathrm{~mm}$ it can be concluded that the cement is not suitable for the production of self-compacting UHPC. If the flowability of the standard recipe is higher than $300 \mathrm{~mm}$, the cement is suitable for UHPC and the $\mathrm{w} / \mathrm{c}$ ratio will be reduced to 0.25 . If the haegermann flow is still higher than $300 \mathrm{~mm}$, the SPcontent will be reduced step-by-step.

According to the determination of the fresh-concrete properties in Figure 1, all 8 types of cement are suitable for the production of self-compacting UHPC, as Figure 2 demonstrates. Consequently, the recipes for all types of cement have been fixed. Figure 2 also shows the final volume of paste and $\mathrm{w} / \mathrm{c}$ ratio.

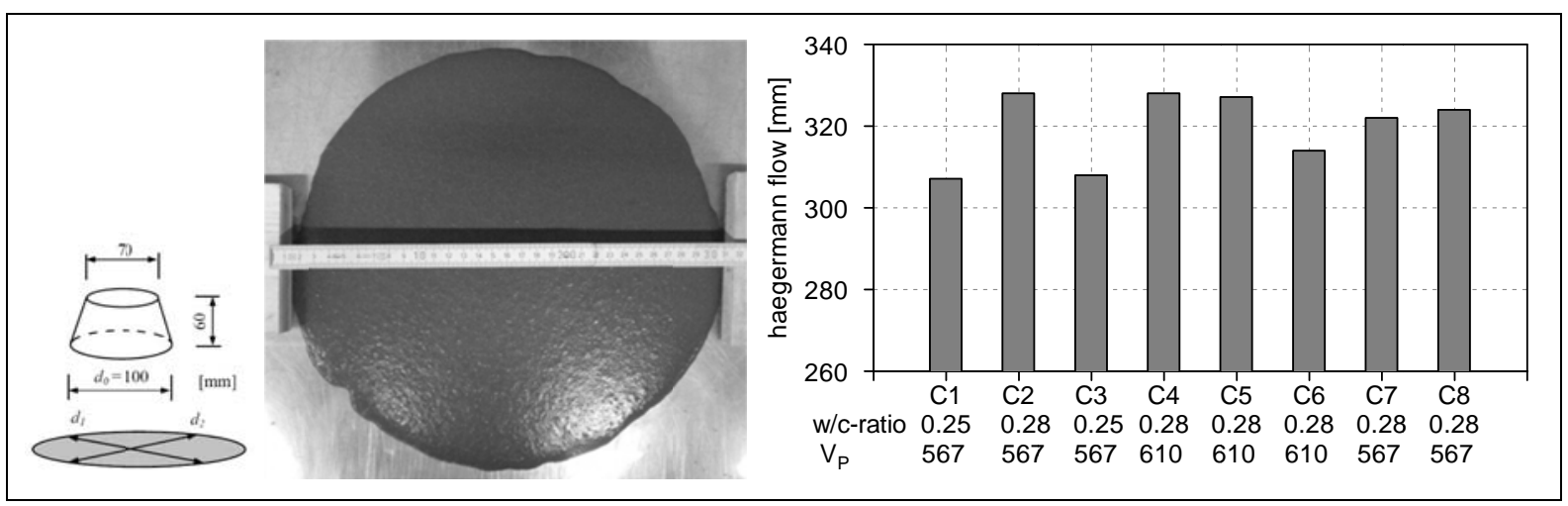

Figure 2. Spread flow test $>300 \mathbf{~ m m}$ (left) and test results (right) including used volume of paste and $w / c$ ratio 
Influence of cement type and type of aggregate on the fresh and hardened properties of UHPC

\subsection{Test results}

For each type of cement, 3 cubic and 3 cylindrical specimens (edge length $100 \mathrm{~mm}$ or $\mathrm{L} / \mathrm{D}=200 / 100 \mathrm{~mm}$ ) have been manufactured to determine the cubic compressive strength and the cylindrical strength as well as the elastic modulus according to ONR23303 (Austrian Standards Institute, 2010d). Further, 6 prisms $(1 \times \mathrm{h} \mathrm{x} \mathrm{w}=160 \times 40 \times 40 \mathrm{~mm})$ have been cast to determine the flexural tensile strength (span $100 \mathrm{~mm}$ ).

The concrete for all specimens have been produced using an Eirich intensive mixer. Subsequent to casting, the free concrete surface has been covered with a plastic sheet for a duration of 24 hours. The specimens for compressive strength and elastic modulus testing have been stored in an air conditioned room $\left(20^{\circ} \mathrm{C}\right)$ until testing, which took place after 28 days. The specimens for flexural tensile testing have been cured partially in water and in an air conditioned room.

Table 3 shows the experimental test results. It can be seen that all Portland Cements (except C7) enable compressive strengths higher than $150 \mathrm{MPa}$. However, the results with C4 (Portland Slag Cement) are not sufficient. Based on these results, the cements can be classified in terms of their suitability for UHPC. Three cements $(\mathrm{C} 1, \mathrm{C} 2, \mathrm{C} 3)$ are suitable for the production of UHPC, three useful (C5, C6, C8) and two (C4, C7) are classified as unsuitable. Due to the scattering of the raw materials, only the three suitable cements $(\mathrm{C} 1, \mathrm{C} 2, \mathrm{C} 3)$ are recommended in order to permanently ensure compressive strengths larger than $150 \mathrm{MPa}$ under site conditions.

Table 3. Test results with UHPC

\begin{tabular}{|c|c|c|c|c|c|c|c|c|c|c|c|c|}
\hline & \multirow{2}{*}{ cement } & \multirow{2}{*}{$\begin{array}{l}\text { blaine } \\
\text { value }\end{array}$} & \multirow{2}{*}{$\begin{array}{c}\text { water } \\
\text { demand } \\
\text { EN } \\
196-3\end{array}$} & \multicolumn{2}{|c|}{ recipe } & \multirow{2}{*}{$\sigma_{\text {cyl. }}$} & \multirow{2}{*}{$\sigma_{\text {cube }}$} & \multirow{2}{*}{$\begin{array}{c}\text { E- } \\
\text { modulus }\end{array}$} & \multicolumn{2}{|c|}{$\begin{array}{l}\text { flexural tensile } \\
\text { strength }\end{array}$} & \multicolumn{2}{|c|}{$\begin{array}{c}\text { direct tensile } \\
\text { strength (equ. 1) }\end{array}$} \\
\hline & & & & $\mathrm{w} / \mathrm{c}$ & $\mathrm{V}_{\text {Paste }}$ & & & & $\begin{array}{l}\text { air } \\
\text { cured }\end{array}$ & $\begin{array}{l}\text { water } \\
\text { cured }\end{array}$ & $\begin{array}{c}\text { air } \\
\text { cured }\end{array}$ & $\begin{array}{l}\text { water } \\
\text { cured }\end{array}$ \\
\hline & & {$\left[\mathrm{cm}^{2} / \mathrm{g}\right]$} & {$[\%]$} & {$[-]$} & {$\left[1 \mathrm{tr} / \mathrm{m}^{3}\right]$} & [Mpa] & [Mpa] & [Mpa] & [Mpa] & [Mpa] & [Mpa] & [Mpa] \\
\hline \multirow{3}{*}{$\stackrel{\frac{0}{0}}{\stackrel{\pi}{*}}$} & $\mathrm{C} 1$ & 4500 & $27-28$ & 0.25 & 567 & 162 & 170 & 50500 & 16.2 & 20.7 & 7.1 & 9.1 \\
\hline & $\mathrm{C} 3$ & 3630 & 27 & 0.25 & 567 & 160 & 168 & 50000 & 16.0 & 19.7 & 7.1 & 8.7 \\
\hline & $\mathrm{C} 2$ & 3900 & 27.3 & 0.28 & 567 & 172 & $\begin{array}{c}176 \\
156^{*} \\
\end{array}$ & 51000 & 16.9 & 20.8 & 7.5 & 9.2 \\
\hline \multirow{3}{*}{$\begin{array}{l}\sum_{0} \\
0 \\
O\end{array}$} & C6 & 5415 & 30.4 & 0.28 & 610 & 162 & 166 & 48500 & 15.9 & 18.4 & 7.0 & 8.1 \\
\hline & C5 & 4150 & 27.7 & 0.28 & 610 & 154 & 157 & 47000 & 15.8 & 20.6 & 7.0 & 9.1 \\
\hline & $\mathrm{C} 8$ & 4600 & 29 & 0.28 & 567 & & 162 & & 16.7 & 20.0 & 7.4 & 8.8 \\
\hline \multirow{2}{*}{ 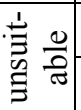 } & $\mathrm{C} 7$ & 2800 & $25-26$ & 0.28 & 567 & & 146 & & 14.3 & & 6.3 & \\
\hline & $\mathrm{C} 4$ & 4400 & 30.4 & 0.28 & 610 & 111 & 115 & 39500 & 12.4 & 16.2 & 5.5 & 7.1 \\
\hline
\end{tabular}

* aggregate sand

The difference between cubic and cylindrical compressive strength is lower in UHPC compared to normal strength concrete due to the lower lateral strain. The elastic modulus for suitable and useful cements is between 47000 and $51000 \mathrm{MPa}$, whereby a strong correlation with the compressive strength has been observed.

Further, the flexural tensile strength lies between 12 and $21 \mathrm{MPa}$, whereby the water cured specimens always have led to higher strength than air cured specimens. The calculation of the direct tensile strength was carried out according to equation (1) (König et al., 2008). 
Influence of cement type and type of aggregate on the fresh and hardened properties of UHPC

$$
f_{c t m}=f_{c t, f l} \cdot \frac{1,5 \cdot\left(h / h_{0}\right)^{0,7}}{1+1,5 \cdot\left(h / h_{0}\right)^{0,7}} \quad \text { mith }_{0}=100 \mathrm{~mm} \text { und } h=40 \mathrm{~mm}
$$

In addition, UHPC with cement $\mathrm{C} 2$ was produced with conventional sand as aggregate. Consequently, the compressive strength decreased only by $20 \mathrm{MPa}$, approximately 15 percent. Note that this is only valid for very suitable cements. Due to the high volume of paste, the influence of the type of aggregate is not as big as expected. Obviously, the quality of the paste and in particular the cement is decisive for the compressive strength.

\section{Experimental Investigations on HPC}

The influence of the type of cement on the compressive strength of self-compacting highperformance concrete (HPC) has also been investigated in this research. According to ÖNORM B 4710 (Austrian Standards Institute, 2007) a cubic compressive strength larger than $126 \mathrm{MPa}$ as an average of three 3 specimens is required for high performance concrete with strength class C100/115. Three different types of cements have been investigated, C2, C6 and C8.

\subsection{Method}

Two different concrete mixtures were investigated, which turned out to be useful in preliminary tests. Compared to the UHPC mixture, the $\mathrm{w} / \mathrm{c}$ ratio has been increased to 0.32 . The volume of paste and the amount of superplasticizer have been reduced accordingly. Conventional sand (0-4 $\mathrm{mm}$ ) and gravel $(4-8 \mathrm{~mm})$ have been used as aggregate. Recipe HPC-1 contains microsilica, quartz powder and limestone powder, recipe HPC-2 only contains limestone powder. Besides cement, HPC-2 contains only inert materials. Table 4 demonstrates the HPC recipes.

Table 4. HPC recipes

\begin{tabular}{|l|l|c|c|c|c|c|c|c|c|c|}
\hline & cement & $\begin{array}{c}\text { microsilica/ } \\
\text { quartz } \\
\text { powder }\end{array}$ & $\begin{array}{c}\text { limestone } \\
\text { powder }\end{array}$ & water & $\begin{array}{c}\text { super- } \\
\text { plasticizer }\end{array}$ & sand & gravel & w/c & $\mathrm{V}_{\mathrm{P}}$ \\
\hline HPC-1 & {$\left[\mathrm{kg} / \mathbf{m}^{3}\right]$} & 500 & 75 & 125 & 160 & 15 & 934 & 939 & 0.28 & 423 \\
\hline HPC-2 & {$\left[\mathrm{kg} / \mathbf{m}^{3}\right]$} & 500 & - & 200 & 160 & 15 & 623 & 626 & 0.28 & 420 \\
\hline
\end{tabular}

${ }^{* 1}$ Microsilica and quartz sand premixed, see (Hadl et al., 2015)

Both HPC recipes have been investigated for cements (C2, C6 and C8), thus 6 mixtures in total. Three cubic specimens (edge length $100 \mathrm{~mm})$ and 6 prisms $(1 \times \mathrm{h} \mathrm{x} \mathrm{w}=160 \times 40 \times 40 \mathrm{~mm})$ have been cast for each mixture to determine the compressive and flexural tensile strength (span $100 \mathrm{~mm}$ ). The concrete for all specimens has been produced using an Eirich intensive mixer. Subsequent to casting, the free concrete surface has been covered with a plastic sheet for a duration of 24 hours. The specimens for compressive strength and half of the prisms have been stored in an air conditioned room $\left(20^{\circ} \mathrm{C}\right)$ until testing, which took place after 28 days. The other prisms have been cured in water.

\subsection{Test results}

The intended cubic compressive strength higher than $126 \mathrm{MPa}$ has been achieved with three selected cements, if recipe HPC-1 had been used. When recipe HPC-2 had been used, the 
Influence of cement type and type of aggregate on the fresh and hardened properties of UHPC

strength is approximately 10 percent lower. This is due to the pozzolanic reaction of microsilica in HPC-1, while HPC-2 contains inert material only. Table 5 demonstrates the test results.

Further, the flexural tensile strength is lower after air curing than after water curing. The difference is not as significant as for UHPC. The calculation of the direct tensile strength was carried out according to equation (1).

Table 5. HPC test results

\begin{tabular}{|c|c|c|c|c|c|c|c|c|}
\hline \multirow{2}{*}{ recipe } & \multirow{2}{*}{ cement } & \multirow{2}{*}{$\begin{array}{l}\text { blaine } \\
\text { value }\end{array}$} & \multirow{2}{*}{$\begin{array}{c}\text { water } \\
\text { demand }\end{array}$} & \multirow{2}{*}{$\sigma_{\text {cube }}$} & \multicolumn{2}{|c|}{ flexural tensile strength } & \multicolumn{2}{|c|}{ direct tensile strength (equ. 1) } \\
\hline & & & & & air cured & water cured & air cured & water cured \\
\hline & & {$\left[\mathrm{cm}^{2} / \mathrm{g}\right]$} & {$[\%]$} & {$[\mathrm{MPa}]$} & {$[\mathrm{MPa}]$} & [MPa] & {$[\mathrm{MPa}]$} & [MPa] \\
\hline \multirow{3}{*}{ HPC-1 } & $\mathrm{C} 2$ & 3900 & 27.3 & 133 & 13.0 & 15.7 & 5.7 & 6.9 \\
\hline & $\mathrm{C} 8$ & 4600 & 29 & 128 & 12.8 & 14.2 & 5.6 & 6.3 \\
\hline & C6 & 5415 & 30.4 & 127 & 12.7 & 13.6 & 5.6 & 6.0 \\
\hline \multirow{3}{*}{ HPC-2 } & $\mathrm{C} 2$ & 3900 & 27.3 & 122 & 11.6 & 13.5 & 5.1 & 6.0 \\
\hline & $\mathrm{C} 8$ & 4600 & 29 & 118 & 12.7 & 13.2 & 5.6 & 5.8 \\
\hline & C6 & 5415 & 30.4 & 116 & 12.2 & 12.8 & 5.4 & 5.6 \\
\hline
\end{tabular}

\section{Discussion}

The experimental test results demonstrate that the compression strength and the fresh concrete properties of HPC and UHPC strongly depend on the type of cement. The cement has to allow a high compressive strength in combination with a low water demand to ensure self-compaction. At the same time, the water demand of the cement depends on the chemical compositions and on the grinding fineness (blaine value). The influence of the chemical composition on the workability and compression strength of UHPC has not been determined in this work. Further, the different fineness levels of cement (blaine value) change the particle size distribution as well as the grading curve in the fine powder and hence the packing density. This influence has also not been taken into account in this investigation.

An evaluation of the UHPC investigation in Figure 3 illustrates that there is no apparent correlation between the blaine value or the water demand of a cement and the suitability for use in UHPC. Therefore, the suitability of cement for the production of UHPC has to be tested experimentally in the future.
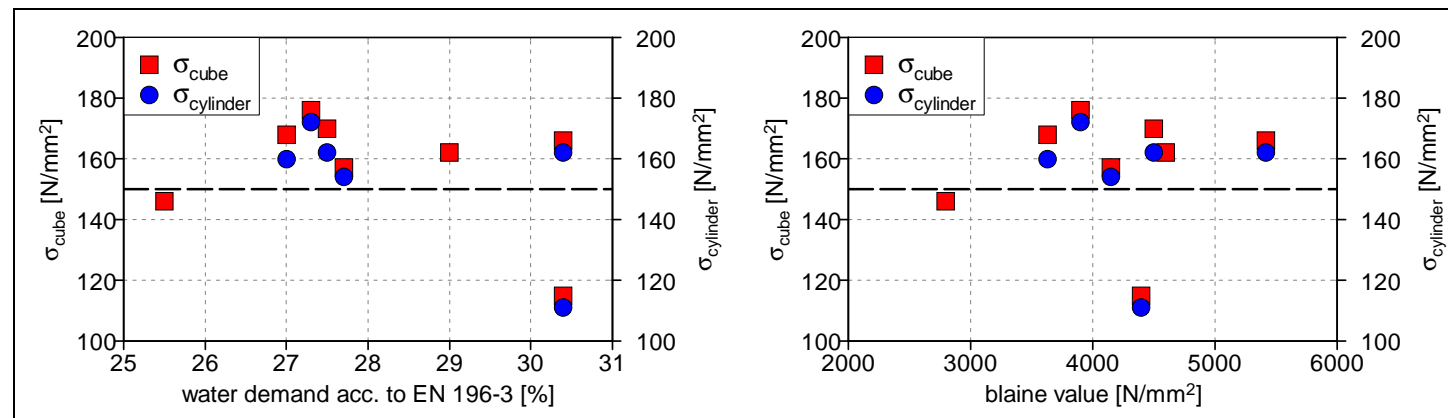

Figure 3. Correlation of water demand (left) or blaine value (right) and the compressive strength 
Influence of cement type and type of aggregate on the fresh and hardened properties of UHPC

Further, the w/c ratio or the w/b ratio are not significant for the compressive strength, as can be seen in Figure 4. Obviously, the type of cement, the grading curve and the packing density are more important for the compressive strength. Figure 4 also demonstrates that the influence of the volume of paste $V_{P}$ is not decisive.
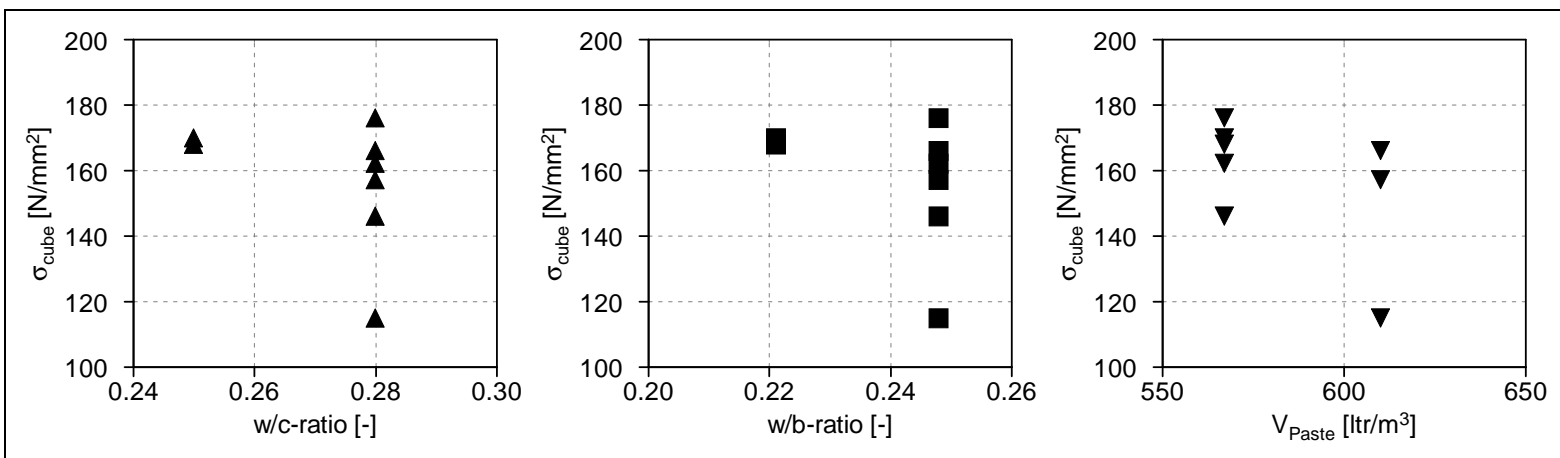

Figure 4. Influence of $w / c$ ratio (left), w/b ratio (centre) and $V_{P}$ (right) on the compressive strength

Based on the test results, it can be concluded that primarily Portland Cements are suitable for the production of UHPC. Portland Slag Cements are only useful in special cases. Compression strengths higher than $160 \mathrm{~N} / \mathrm{mm}^{2}$ are only possible with Portland Cements with low water demand. In this context, $\mathrm{C}_{3} \mathrm{~A}$-free cements have proven effective. The water demand of the cement is decisive for the workability and the mechanical properties of UHPC.

Further, the test results with HPC demonstrate that the quality of the paste is significant for the compression strength of HPC. With a proper kind of cement and a good paste composition, the influence of the aggregate type on the strength is small up to a compressive strength of about $120 \mathrm{MPa}$. The use of microsilica results in an increase in strength of about 10 percent, due to the pozzolanic reaction.

\section{Conclusion}

In this contribution, 8 types of cement from different manufacturers have been investigated for their suitability for the production of HPC and UHPC. To ensure self-compacting properties, the standard recipe had to be adapted for each type of cement. It can be concluded, that the blaine value and the water demand are not sufficient for predicting the suitability of a cement for the production of UHPC. However, a simple method has been developed to quantify unknown cements quickly and safely for this purpose.

The test results demonstrate that compressive strengths and workability strongly depend on the type of cement. In principle, the use of locally available cement is possible. By 6 out of 8 cements, the intended strength higher than $150 \mathrm{MPa}$ after 28 days has been achieved without heat treatment. Due to the scattering of the raw materials, only three cements can be recommended after all.

Further, the influence of the type of cement on the compressive strength of selfcompacting high-performance concrete (HPC) has also been investigated. For this purpose, two HPC recipes, one including reactive microsilica and one with only inert additives, have been used. The intended cubic compressive strength higher than $126 \mathrm{MPa}$ has been achieved with all three types of cement. When using the recipe without microsilica, the strength is approximately 
Influence of cement type and type of aggregate on the fresh and hardened properties of UHPC

10 percent lower. Thus, the influence of the reactive microsilica on the compressive strength is clearly visible. In addition, the influence of the quality of paste is significant for the compression strength. The influence of the aggregate type on the strength is small up to a compressive strength of about $120 \mathrm{MPa}$.

\section{References}

Austrian Standards Institute, “ÖNORM B 4710-1 - Beton - Teil 1: Festlegung, Herstellung, Verwendung und Konformitätsnachweis”, Vienna, 2007.

Austrian Standards Institute, “ÖNORM EN 196-1 - Prüfverfahren für Zement - Teil 1: Bestimmung der Festigkeit”, Vienna, 2010.

Austrian Standards Institute, “ÖNORM EN 196-3 - Prüfverfahren für Zement - Teil 3: Bestimmung der Erstarrungszeiten und der Raumbeständigkeit”, Vienna, 2010.

Austrian Standards Institute, “ÖNORM EN 196-6 - Prüfverfahren für Zement - Teil 6: Bestimmung der Mahlfeinheit", Vienna, 2010.

Austrian Standards Institute, "ONR 23303 - Prüfverfahren Beton (PVB) - Nationale Anwendung der Prüfnormen für Beton und seiner Ausgangsstoffe", Vienna, 2010.

DAfStb, “Sachstandsbericht UHFB”, Berlin, 2007.

De Larrad, F., Sedran, T., "Mixture-proporting of high performance concrete", Cement and Concrete Research, Vol. 32, 2002, pp. 1699-1707.

Fehling, E., Schmidt, M., Walraven, J., Leutbecher, T., Fröhlich, S., “Ultrahochfester Beton”, Betonkalender, 2013, pp. 118-239.

Geisenhanslüke, C., "Influence of the granulometry of fine particles on the rheology of pastes", $\mathrm{PhD}$ thesis, University of Kassel, 2008.

Hadl, P., Kim, H., Tue, N.-V., "A compound for the production of high and ultra-high performance concrete", Proceedings of the 7th RILEM Workshop on HPFRCC, Stuttgart, 2015.

Kim, H., Hadl, P., Tue, N.-V., röger, J., Tue, N.-V., “A New Mix Design Method for Ultra High Performance Concrete based on Stepwise Optimization of Particle Packing Density", Proceedings of Hipermat $20164^{\text {th }}$ International Symposium on UHPC and High Performance Materials, Ed., Fehling, E., Middendorf, B. and Thiemicke, J., Kassel University Press, Kassel, Germany, 2016.

König, G., Tue, N.-V., Schenck, G., "Grundlagen des Stahlbetonbaus - Einführung in die Bemessung nach DIN 1045-1", Wiesbaden, 2008.

Leutbecher, T., "Rissbildung und Zugtragverhalten von mit Stabstahl und Fasern bewehrtem Ultrahochfesten Beton (UHPC)", PhD thesis, University of Kassel, 2012.

Reichel, M., "Dünnwandige Segmentfertigteilbauweisen im Brückenbau aus gefasertem Ultrahochleistungsbeton (UHFB) - Tragverhalten, Bemessung, Konstruktion”, PhD thesis, Graz University of Technology, 2010.

Richard, P., Cheyrezy, M., "Composition of Reactive Powder Concretes”, Cement and Concrete Research, Vol. 25, 1195, pp. 1501-1511. 